\title{
Homeowners' Willingness to Make Investment in Energy Efficiency Retrofit of Residential Buildings in China and Its Influencing Factors
}

\author{
Ce Huang ${ }^{1}$, Jiefang $\mathrm{Ma}^{2}$ and Kun Song ${ }^{1, *}$ \\ 1 School of Architecture, Tianjin University, Tianjin 300072, China; huangce@tju.edu.cn \\ 2 Faculty of Architecture and the Built Environment, Delft University of Technology, \\ 2628BL Delft, The Netherlands; J.Ma-1@tudelft.nl \\ * Correspondence: sklqm@tju.edu.cn
}

check for updates

Citation: Huang, C.; Ma, J.; Song, K. Homeowners' Willingness to Make Investment in Energy Efficiency Retrofit of Residential Buildings in China and Its Influencing Factors. Energies 2021, 14, 1260. https:// doi.org/10.3390/en14051260

Academic Editor: Benedetto Nastasi

Received: 13 January 2021

Accepted: 15 February 2021

Published: 25 February 2021

Publisher's Note: MDPI stays neutral with regard to jurisdictional claims in published maps and institutional affiliations.

Copyright: (c) 2021 by the authors. Licensee MDPI, Basel, Switzerland. This article is an open access article distributed under the terms and conditions of the Creative Commons Attribution (CC BY) license (https:// creativecommons.org/licenses/by/ $4.0 /)$.

\begin{abstract}
In China, energy efficiency retrofit of residential buildings is entering a new stage in which homeowners are the main subject. In order to investigate homeowners' willingness to invest and to analyze its influencing factors, interviews and a questionnaire survey were conducted in central Tianjin, China. The results show that homeowners have a certain willingness to invest in energy efficiency retrofit but that their willingness to pay (WTP) is far from enough to cover the total cost. Among the influencing factors, the homeowner's age, education level, and retrofit experience as well as the age and floor area of their home are significantly related to their WTP. The reasons for the impact of these factors are further discussed, including the influences of China's previous housing policies and retrofit policies. Policy recommendations to promote investment by homeowners are suggested based on the findings.
\end{abstract}

Keywords: energy efficiency; residential retrofit; willingness to pay; homeowner

\section{Introduction}

Residential buildings in China account for a significant share of the end use energy consumption. High level of energy consumption in residential buildings has an adverse impact on both residents' living conditions and the national strategy of energy conservation. Energy efficiency retrofit of residential buildings can decrease the cost of heating and cooling as well as improve the indoor thermal comfort level. Currently, a large amount of energy-inefficient residential buildings needs to be retrofitted in China. In the previous energy efficiency retrofit projects, the homeowners rarely make contributions. In the recent years, the State Council of China has been exploring new financing mechanism of residential retrofit. The initiative and the cost will be shared by the residents, the government and other stakeholders together, and the pure government-led model will be replaced. In order to help policymakers to design the new mechanism, it is crucial to understand and analyze homeowners' willingness to pay and its influencing factors.

Energy efficiency retrofit of existing residential buildings is an important target of the national strategy of energy conservation [1]. It can improve the energy performance of the building and the living conditions of the residents [2]. In China, there are more than 100 million residents living in 170,000 existing residential districts built before 2000. Most of apartment buildings in these residential districts need a comprehensive retrofit, including energy efficiency retrofit. The MOHURD (the Ministry of Housing and Urban-Rural Development) had started pilot retrofit projects in 15 cities since 2017. Until December 2018, a sum of 106 pilot projects had been carried out [3]. Following that, many retrofit projects have been completed in China. However, there are still a great number of residential buildings awaiting to be retrofitted.

In the current situation of energy efficiency retrofit, the responsible subjects and benefited subjects are misaligned. The stakeholders involved in the process include the 
government, design and construction companies, heat supply companies, residents, and financing companies. Homeowners are the direct and main benefited subject, as the retrofit will not only improve the energy efficiency and comfort level but also increase the value of their homes [4]. However, homeowners are seldom systematically involved in retrofit projects. In the past decades, retrofit projects have been carried out under a government-led model as a political task. The government takes the major initiative [5], while homeowners' participation ratio is low [6]. The current mechanism, which had caused increased pressure for the government in terms of managing and financing the retrofit projects, is unhealthy and unsustainable [7].

In recent years, more reasonable processes and financing mechanisms of retrofit have been discussed by experts and researchers. Previous studies have shown that homeowners' investment and participation is essential in boosting the energy efficiency retrofit of residential buildings [8]. China's government has also realized that the homeowners' responsibilities need to be fulfilled. In 2020, the General Office of State Council in China published the principle of "who benefits, who contributes" to promote the implementation of homeowners' capital responsibilities [9]. The detailed mechanisms of financing are being discussed. For the new mechanism to function healthily, it is necessary to find a way to encourage homeowners to invest. In order to provide references for the government to propose targeted policies and regulations to encourage homeowners, their willingness to make investment and its influencing factors on energy efficiency retrofit need to be analyzed [10].

Both qualitative and quantitative methods have been used to study homeowners' willingness to invest in energy efficiency retrofit [11,12]. The former, which usually include interview and focus group, can be used to investigate homeowners' barriers and motivations and to understand their attitudes and willingness from a broader view. The latter, on the other hand, is more commonly realized by using a questionnaire survey and aimed to estimate the WTP and to measure the extent to what the potential influencing factors can affect the intention.

The primary function of qualitative studies is to generally understand factors influencing the willingness to make investment, especially factors that are hard to be quantified. Previous qualitative studies mainly focus on the stated motivations and barriers. Friedman studied Israeli homeowners' concerns and found they worry about small direct economic benefits and long payback period [13]. Klockner found the main reasons for Norwegian homeowners not to make investment towards retrofit were long construction period and "the feeling that the right time has not come yet" [14]. Alberini believed both homeowners" resistance towards the construction work and their concern about energy prices have a negative influence on their willingness to make investment [15]. High upfront cost has been identified as a barrier in Switzerland [16], Germany [17], Denmark [18] and the United States [19]. However, Wilson and Jakob did not find it to have a significant influence on homeowners in the UK and Switzerland [20,21].

Among the quantitative methods, a common approach is to evaluate homeowners' WTP. This approach has been widely applied in the microeconomics domain, and has been introduced into the research area of building retrofit. It can contribute by exploring homeowners' willingness to make investment, quantifying the monetary amount that they are willing to pay for a certain project, and revealing its relevant factors [22].There are several methods to collect the consumer's WTP. Considering residential energy efficiency retrofit's nature as an uncommon good, calculation by consumers' stated preference collected through surveys has been most commonly used [23]. Banfi, Achtnicht, Kwak, Vance and Collins have respectively estimated residents' WTP for energy efficiency retrofit in several countries, including Switzerland [16], Germany [17], Korea [24], Germany [25] and Ireland [26]. Researchers in different countries has reported deviated survey results. The results of the WTP can also be reported in diverse ways. For example, Banfi used the proportion of the dwelling's value, Kwak measured it by US dollars, and both Vance and Collins calculated residents' WTP by per kWh per year. 
It is also necessary to analyze the correlation between several potential influencing factors and homeowners' willingness to pay. These factors can be categorized as follows: respondents' individual factors (biological and social attributes), building features of the home, policy factors and other factors. Among respondents' individual factors, age is usually identified as a negative factor, while education level is often positively related to the WTP. There is no consistent result for income level and gender. According to the studies of Achtnicht, Nair, Poortinga, and Gamtessa, elder homeowners in Germany [17], Sweden [27], the Netherlands [28] and Canada [29] are less willing to make investment towards energy efficiency retrofit. Achtnicht and Nari agreed that higher education level would bring higher WTP $[17,27]$. Some researchers believed that income will influence investment behavior in Denmark [30], the United States [31-33], and the United Kingdom [34], while others did not find a significant correlation [35,36]. Banfi found high-income families are more willing to make investment towards energy efficiency retrofit [16], while Gamtessa believed low-income population in Canada is more willing to make investment to gain profit [29]. Phillips suggested that people affected by energy poverty cannot afford the cost of energy efficiency facilities [37]. Lacking knowledge and information about energy efficiency retrofit is considered as a negative influencing factor [38]. Among residential building features, it is commonly suggested by previous studies that the higher the age of the building is $[15,20]$, and the lower the thermal comfort level is [21,39], the more the residents' willingness to invest in energy efficiency retrofit would be. As for the floor area of the building, Gamtessa believed it to have a negative influence on the WTP [29], while Nauleau holds the opposite opinion [40]. In addition, both residential building's climate region and its location in the city can affect WTP [41]. The delivery method of the questionnaire would also influence residents' opinions [42].

In terms of policy factors, governments of many countries and regions provide financial incentives to promote energy efficiency retrofit. However, it remains a debate whether these measures are efficient. Some researchers believed these financial incentives can stimulate energy efficiency retrofit. Some suggested higher subsidies can help to execute more retrofit projects [13], while some others are against this idea [43].

Qualitative and quantitative studies can reinforce and complement each other. Interview can help to have a general idea of homeowners' attitude and willingness towards investing in retrofit, but cannot it can neither distinguish the most important factors, nor identify the factors that can be generalized to a larger population. Quantitative studies can help to reveal the statistical correlation, but there are also some drawbacks. Firstly, statistical correlation does not equal to logical causality. Secondly, in homeowners' investment decisions, there are many factors that cannot be quantified. Some factors could even play a one-vote veto role. The analysis of homeowners' willingness needs a combination of qualitative and quantitative methods.

A combined discussion can reveal underlying reasons for the influencing factors. For example, researchers have found different explanations for elder homeowners' lacking willingness to make investment: Mahapatra believed they are not sure if the investment would pay back during their residence period [44], Black believed they concern less about the energy situations [31], Poortinga believed they are also low-income population [28], and Lindén believed they have less knowledge about energy-saving measures [45].

Some domestic studies have also touched upon energy efficiency retrofit's financial aspect. For example, Yuming studied how to promote energy efficiency retrofit from a national economic policy perspective [46], and Yi discussed the promotion of heat metering [47]. However, there lack studies focus on the homeowner's perspective. Facing the upcoming institutional reform, in which homeowners will become the main body of energy efficiency retrofit, it is more necessary than before to analyze and summarize homeowner's attitude and intentions. The findings of this paper can fill the gap in previous studies.

The aims of this study are to explore the possibility for homeowners to make investment towards energy efficiency retrofit of their home by evaluating their WTP and to reveal the factors that influence their decision. The findings can provide references and directions 
for policymakers to design administrative measures to encourage homeowners to invest, so that the funding structure of an energy efficiency retrofit project in China can be optimized. A healthy funding structure promotes rapid progress of energy efficiency retrofit, and then, considerable energy can be saved. In the second section, the current situation of residential energy efficiency retrofit in China and Tianjin will be introduced, followed by backgrounds of the current policy and typical building characteristics. The third section presents the methodology. The fourth section describes and analyzes the results. Based on the results, the fifth section discusses the possibility for homeowners to invest in retrofit and propose potential policy incentives. The final section gives conclusions and suggests further research directions.

\section{Research Background}

\subsection{Residential Energy Efficiency Retrofit in China}

Building energy consumption accounts for $21.10 \%$ of the total energy consumption in China. The energy consumption of residential buildings in cities and towns is 361 mtce per year, which is $38.09 \%$ of the whole building sector [48]. Because of the climate conditions and economic level, both of the total building energy consumption and its composition vary among different regions. Building energy consumption is significantly higher in economically developed cities in the northern heating region [48]. Due to the low level of construction quality and design standards, most of the residential buildings built before the 2000s are energy inefficient. The insulation performance of the external walls is approximately $1 / 3$ of that of similar buildings in developed countries on the same latitude [49]. The situation is even worse in north China. Compared to similar buildings in the global north, the heat loss of the external walls is $3-5$ times, and that of the external windows is 2 times [50].

According to Special Planning for Medium and Long Term Energy Conservation (National Development and Reform Commission, 2004), compared to reference building built in the 1980s, newly-built and retrofitted buildings should reduce energy consumption by $50 \%$. The standard has been upgraded to $65 \%$ later. During the 13 th National Five-Year plan, energy efficiency retrofit in the northern heating region should be finished by 2020. However, the target is not reached until now. Meanwhile, the "65\%" standard of China only equal to the standard in Germany in the 1990s, and higher standards is expected soon. There is still great energy-saving potential in the retrofit of existing buildings.

\subsection{Residential Energy Efficiency Retrofit in Tianjin}

The measures of residential energy efficiency retrofit depend on the building's features and the climate environment of the region. In this study, the data is mainly collected in Tianjin, a city that has a warm temperate semi-humid continental monsoon climate. Based on the division of five climate regions in China, Tianjin is located in the Cold Zone, where the winter is cold and dry and the summer is hot. In this region, the design code of residential buildings acquires good thermal insulation and heat supply in winters.

Currently, the existing housing stock in Tianjin is 226 million square meters, among which $48 \%$ are built after 2005 and thus can meet the newest energy conservation standard. The rest were built before 2005, among which 37\% were built between 1996 and 2007, and have long lifespan expectancy as well as large retrofit potential. Apart from the poorly insulated building envelop, these residential buildings also cannot meet the demand of residents in terms of function, usable area, construction quality, etc. In Tianjin, the district heating system is widely applied as a compulsory urban infrastructure. Currently, the cost of district heating is calculated by the floor area.

Large-scale efficiency retrofits started to take place in Tianjin in 2006. A total of 61.2 million square meters of residential buildings have been retrofitted by 2017. Main energy-saving measures include building insulation such as wall insulation, roof insulation, balcony and staircase insulation, replacing doors and windows; improvement of heating 
supply system efficiency; heat metering. However, in practice, most of the heat metering devices, which were funded by the local government, had never been used [51].

\subsection{The Transformation of China's Housing Policy and Forms}

The form of housing property and market price also has an impact on homeowners' investment. In the past decades, China's housing market has experienced a complete transformation. During the 1950s to 1980s, under the welfare housing policy, the property right of land and residential buildings belongs to either the country or state-owned enterprises. In 1980, the housing commercialization policy was put forward. The physical housing allocation system was terminated in 1998, and housing in cities and towns transformed from welfare products to commodities. The tenants of welfare housing can purchase housing property from the government and become homeowners. In the past 30 years, because of the large-scale construction of commercial housing and the privatization of welfare housing, the proportion of private housing has increased rapidly.

The most common form of housing in cities and towns in China is multi-unit apartment buildings. The property right of each unit belongs to a private homeowner, and all the homeowners of one apartment share the property right of common areas, such as the staircase and the basement. Therefore, most energy efficiency retrofit measures need to be carried out towards the entire building, including both private and common areas. According to the Civil Code of the People's Republic of China, large-scale maintenance such as energy efficiency retrofit can only be executed with the agreement of more than $2 / 3$ co-owners.

After China's Reform and Opening-up, because of the rapid economic growth, China's building standard of residential buildings has been improved to meet people's growing demand for living conditions. The floor area became larger and the construction quality has been enhanced [52]. There is also an improvement of the residential building's structure and material, which would bring an increase in both housing quality and comfort level [53].

\section{Methodology}

The methodology of this study consists of two parts. The first part is the in-depth interview of homeowners. After being provided some necessary knowledge and information, the homeowners were asked about their attitude towards energy efficiency retrofit, their intention to invest in it, and the drivers and barriers that they were concerned about. The second part is a questionnaire survey based on the literature review and the results of in-depth interviews. In this part, residents' willingness to pay and its influencing factors are revealed and quantified.

\subsection{In-Depth Interview}

The study was carried out in the city of Tianjin, one of the four municipalities directly under the jurisdiction of the central government of China. It is a typical metropolis in the Cold Zone of China with a population of 15,596,000 (data from 2018). The interviews were conducted in the city center, where residential buildings built in different eras can be found. In order to achieve maximum diversity, 14 residential districts built in the 1980s, 1990s and 21st century were selected, including retrofitted ones and unretrofitted ones.

The data collected from this approach was mainly from face-to-face interviews and observation. The idea of data sampling is to select as representative as possible interviewees. The quality of the conversation is more important than the quantity, thus the whole process will be terminated if no new idea turns out [54]. To ensure that the interviewees have a full understanding of the residential condition, their length of residence must be no less than three years. The proportion of respondents with and without retrofit experiences was also balanced to represent both of these groups. Homeowners were interviewed in the selected residential communities at outdoor places that are suitable for a short-time stay and chat. In order to ensure the diversity of the sample in terms of social-demographic characteristics, the interview was carried several times in different periods of the day. 
As mentioned above, the main purpose of the interview is to guide the homeowners in expressing their concerns about the retrofit and their barriers and motivations. All questions were designed to achieve that purpose. In order to design the guideline for the interview, a pilot interview of two homeowners and two professionals with energy efficiency retrofit experiences was carried out before the formal semi-structured interview. The formal interview consists of two parts. The social-demographic characteristics of the respondents and the feature of their residential buildings were asked at the beginning, followed by a themed interview. As shown by the flow chart (Figure 1), the respondents were asked to describe their drivers or barriers towards energy efficiency retrofit, as well as their intention to invest. Then, the interviewers would ask them more questions based on their profile and their answers. All the questions were focused on the possibility to invest in retrofit and its influencing factors.

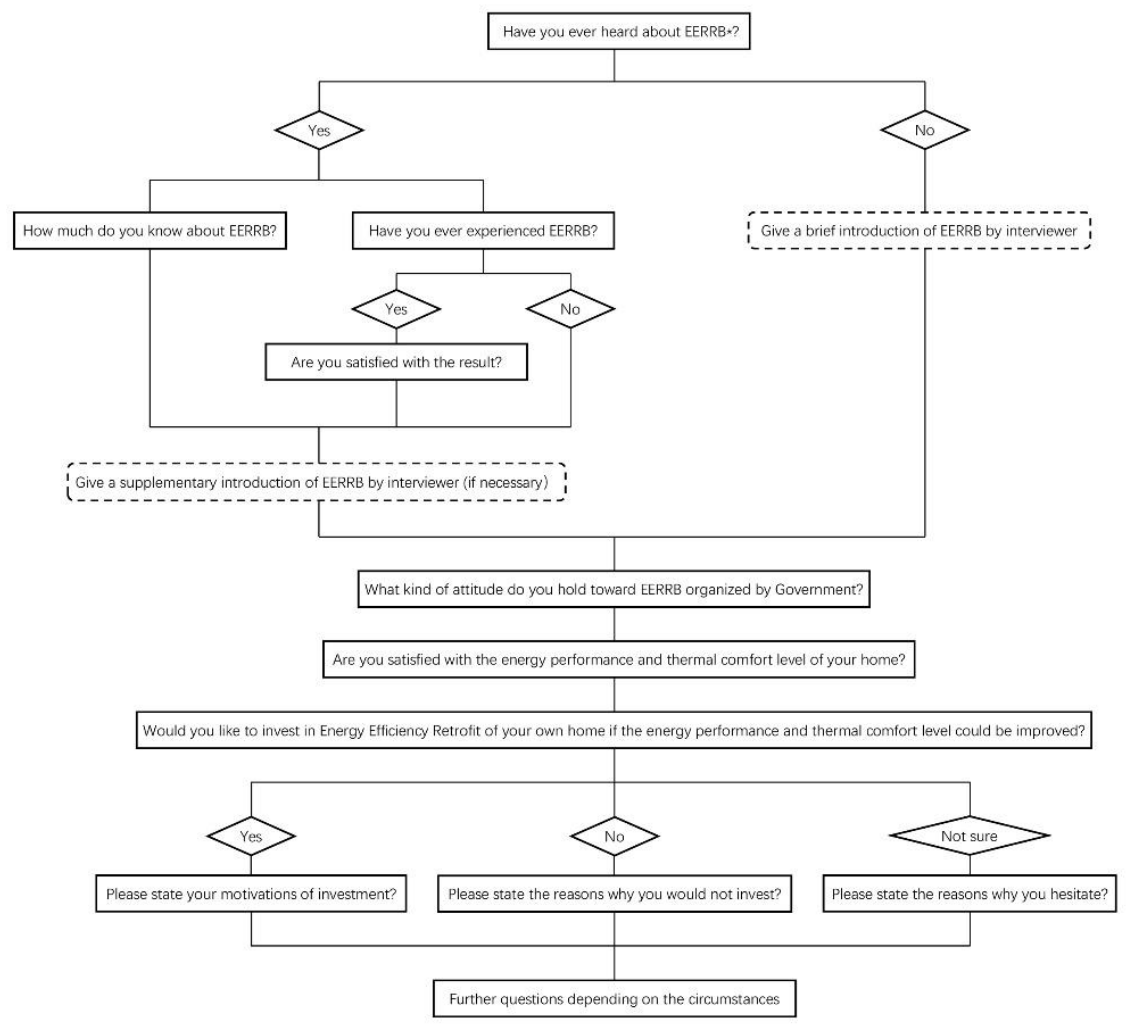

Figure 1. Structure of prepared questions at the beginning of interview. EERRB* stands for energy efficiency retrofit of residential building

From June to July 2019, a sum of 24 homeowners (15 female, 9 male) in the target residential communities were interviewed (see Appendix A). Their age ranges from 30 to $75(\mathrm{M}=52.25, \mathrm{SD}=14.57)$. Their properties were built from 1983 to 2002. All the interviews were carried out in Mandarin Chinese. The length of the interviews was from 20 minutes to 40 minutes. The transcripts were transcribed into electronic documents.

\subsection{Questionnaire}

The questionnaire was allocated randomly face to face in the same area of in-depth interview and then collected on the spot. Any questions posed by the interviewee could be answered in time. Auction was used to investigate the respondents' willingness to pay [23]. We firstly introduce the approximate cost and benefit of the retrofit. Since heat metering is not yet executed successfully in Tianjin, the questionnaire was under the hypothetical premise that the heating supply company will decrease the cost by the energy performance of the home after the retrofit. It was made clear to the respondents that undertaking the retrofit would take both time and monetary cost, and that they would benefit from the 
increased value of the property and the improved living comfort level. Then they were asked to indicate how much they would like to pay for the retrofit. They can choose from "0", "20\%", " $50 \% "$, " $80 \% "$, and "100\%" of the total cost of the retrofit.

Based on the literature review and the analysis of the interview results, some factors that may influence their willingness to pay were presented in the questionnaire, including the following three aspects: the feature of the home, such as floor area, year of build, etc.; the social-demographic characteristics of the respondent, such as age, gender, highest education level, and income; the respondent's experience and opinion about energy efficiency retrofit. Each factor was designed and incorporated into the questionnaire as a radio button or fill-in-the-blank question (see Appendix B).

A pilot survey of 10 respondents was carried out prior to the massive allocation. After collecting 50 copies, the questionnaire was evaluated and adjusted based on the existing answers to ensure the respondents' sufficient understanding of the questions. A total of 484 questionnaires were distributed, and 367 valid questionnaires were used in this paper after screening based on verification questions and completeness. The sample contained 221 female and 146 males ( $\mathrm{M}$ age $=40.29 ; \mathrm{SD}=12.69$ years). The age and gender distributions of the respondents are shown in Figure 2.
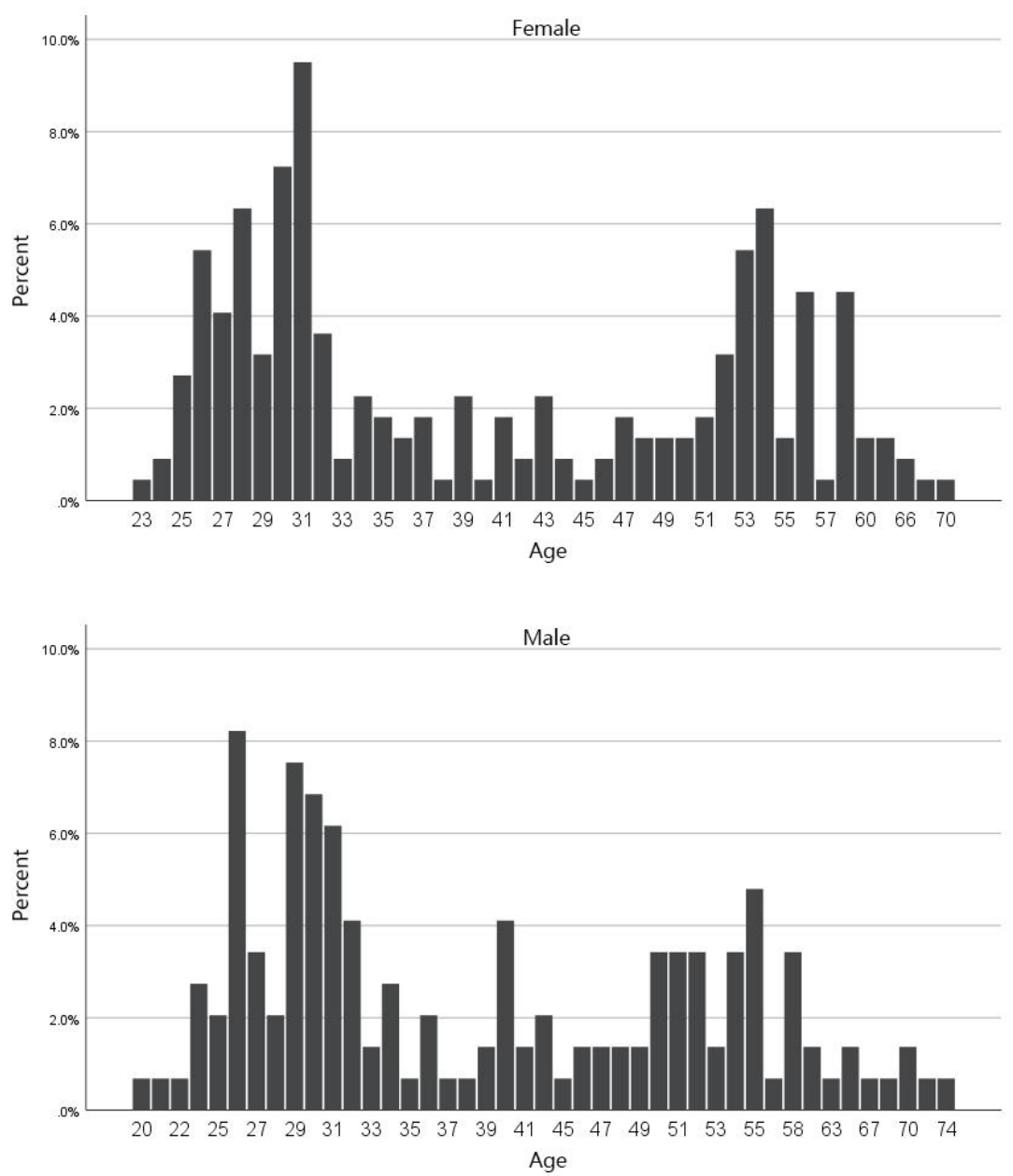

Figure 2. Age and gender distribution of the respondents.

The education level distribution of the respondents is shown in Figure 3. The sample characteristics were more representative of the central area than the city of Tianjin. 


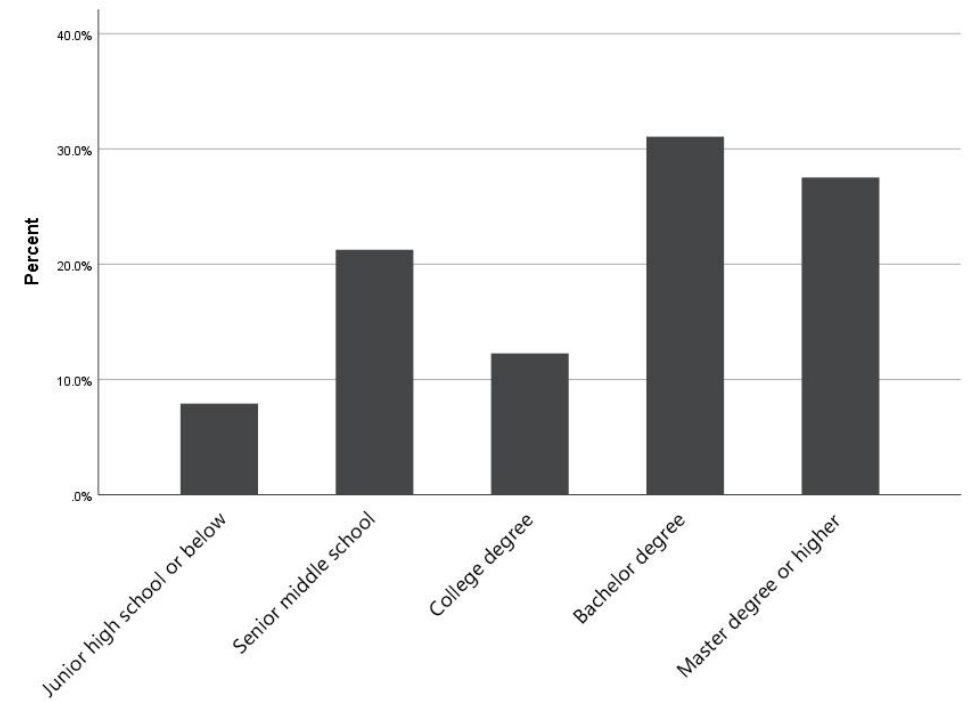

Figure 3. Education level distribution of the respondents.

\section{Results}

\subsection{Results of In-Depth Interview}

4.1.1. Homeowners' Knowledge, Attitude, and Willingness to Invest

Most of the interviewees indicated that they have some knowledge about residential energy efficiency retrofit. They have gained knowledge by media, posters, and slogans in the residential community, communication with friends, or internet social media, etc. Those who have undertaken a retrofit have a deeper understanding of the retrofit measures and expected outcomes, and some even have professional knowledge such as the structure and material. Meanwhile, they have a diverse attitude towards energy efficiency retrofit. Most of the interviewees are positive about the target of the retrofit, while the others show no concern. Some interviewees that have participated in government-led retrofit projects even expressed their disappointment about the construction quality, retrofit outcomes, and the efficiency of the government. Part of the interviewees is satisfied with the current energy performance, while others expect it to be improved.

Talking of the willingness to invest, only 6 interviewees indicated that they are willing to bear part or the entire cost. Among them 3 mentioned that they have already retrofitted their home on their own expenses: R2 insulated the interior walls, R23 and R24 replaced the heating radiator. There were 13 interviewees that do not want to invest, and 5 interviewees were not sure before they have more information.

\subsubsection{Drivers and Barriers for Making Investment}

\section{Drivers:}

The most common drivers are comfort level and financing, and the former was mentioned far more than any others. As mentioned by the three homeowners who have spontaneously retrofitted their homes, because of the poor insulation performance or insufficient heat supply, the indoor temperature was not warm enough. Thus, they hired professional companies to retrofit their homes for a better indoor comfort level. The other three homeowners showed similar concerns and have not taken action yet.

R24: "The cost of the retrofit is hardly comparable to the current housing value. My main concern is the comfort level."

When asked about the economic benefits of the retrofit, interviewees were not sure about how this can be achieved. After the interviewer introduced possible economic incentives for energy efficiency retrofit (such as government subsidies, reduced heating costs, and increased market value of the property), some homeowners expressed their 
willingness to change their minds and consider investing in retrofit if the economic benefits can be obtained.

Different from others, R4 expressed the reason for the willingness to invest as, if the energy efficiency retrofit is promoted by the government, then it is reliable and thus he would be willing to support it.

Barriers:

Compared with the drivers, more barriers were proposed by the interviewees in the initial stage and the targeted questioning stage of the interview. These barriers can be summarized as personal factors, housing factors, responsibility definitions, and policy factors.

The most mentioned personal factor is insufficient funds. Some homeowners have a sufficient understanding of the advantages and processes of energy efficiency retrofit but cannot afford the cost.

R13: The retrofit is indeed a good thing, and I have also learned that the retrofitted home is more comfortable, but I have no money for that.

When asked whether they would accept targeted loans provided by banks, some homeowners expressed their willingness to take loans for retrofit. Another barrier that was often mentioned was the age of the homeowner. Some homeowners said that considering their age, it is not sure how long they can continue living in the current home, and there is a chance that the investment towards retrofit is not worthwhile.

R9: The insulation of the current home is really not good, and I also hope to live in a more comfortable place. But since I am already at this age, I don't know how long I can continue living here after spending so much money.

In terms of housing factors, some homeowners said that they are very satisfied with the current indoor environment and there is no need for retrofit at all. Other homeowners said that the biggest shortcoming of the current residence is the insufficient living area, which cannot be improved by the energy efficiency retrofit. It is also mentioned by some homeowners that the structure of the building is too old so they intend to move out instead of undertaking a retrofit.

R12: My current residence has a prefabricated panel structure. On the one hand, I feel that this structure is outdated and the safety is much more inferior compared to the framed concrete structure. On the other hand, I have also learned that the retrofit outcome of prefabricated buildings is not as good as that of the newly built buildings.

R19: Compared to energy efficiency retrofit, I prefer the residential building being demolished. I know what kind of changes can be brought about by energy efficiency retrofit and other types of retrofit, and I also know that the thermal insulation will be improved after the retrofit. But my home is too small and the layout is very unreasonable. I don't think the retrofit can solve my problem.

The property value is also one of the factors considered by the homeowners. They believe that their investment in energy efficiency retrofit cannot increase the selling price and thus it is not worthwhile to retrofit.

The definition of responsibility for energy efficiency retrofit has received extensive attention from homeowners. Many homeowners believe that it is other stakeholders' responsibility for investing in energy efficiency retrofit. Some believe that the government or developers should be responsible because their homes were purchased from the government or developers, so the government or developers should bear the after-sales responsibility. Some think that the construction company should be responsible because they are those who built the buildings that do not meet the energy-saving standards and other construction work needs to be carried out. Others believe it belongs to the heating supply company, because the heating cost can be reduced after the retrofit, and the heating company as the direct beneficiary should take the responsibility to invest.

R18: My current home used to be public housing, and I bought it from the government. Although the property rights belong to me, the government cannot ignore the responsibility if it needs to be retrofitted. 
R20: I think it is the government's responsibility to guarantee the people's well-being. The retrofit involves energy-saving and environmental protection as well as improving people's quality of life, which should be the responsibility of the government.

Policy factors also have many influences, among which the issue of fairness is the most mentioned. Homeowners with different levels of willingness all mentioned that the retrofit projects mainly funded by the government have improved the surrounding residents knowledge of energy retrofit, but have also brought some side effects. Interviewees felt that there is no reason for homeowners to make investments since the previous retrofit projects were mainly funded by the government. Considering the main urban renewal policy of Tianjin was demolition and relocation in the past 10 years, the most familiar and acceptable procedure for homeowners is to sell their homes to the government and get a relocation allowance. Homeowners are also worried the retrofit will become a waste if their homes would be demolished in a short time.

Interviewees mentioned some other barriers. For example, some homeowners have participated in government-led retrofit before, and are dissatisfaction with the outcome because of defects such as poor construction quality, unreasonable fees, and poor ventilation in the summers. Some worry about their daily lives being disturbed during the construction period, such as generating too much noise and dust, the construction time being too long, and miscellaneous people in the community; some worry that the retrofit will affect the structural safety, fireproof performance, facade aesthetics, and existing decoration of the building; some worry that the retrofit cannot be carried out smoothly if their neighbors are unwilling to invest; some have concerns about the unknown situations and are thus hesitate to put their energy in it.

\subsection{Questionnaire Results}

Results indicate that among all the respondents, $35.4 \%$ have retrofit experience, while $64.6 \%$ do not. Besides, $38.0 \%$ think they have enough knowledge about the retrofit of old residential communities, $49.4 \%$ think they have some knowledge, and $12.7 \%$ have no knowledge at all.

Regarding the willingness to pay, $27.5 \%$ of the respondents indicate that they were willing to pay for the retrofit cost in full, $46.9 \%$ are willing to pay part of the retrofit cost, and another $25.6 \%$ are unwilling to pay for the retrofit (Table 1 ). As mentioned above, for collective housing, under the current Chinese "Civil Code of the People's Republic of China", the retrofit of the whole building can only be executed if more than two-thirds of the homeowners agree. Assuming that homeowners with a high WTP are willing to accept a lower payment price, if the government organizes the retrofit and requires homeowners to invest $100 \%$, according to the results of the questionnaire, $27.5 \%$ of the homeowners would agree; If required to invest $80 \%$, homeowners that willing to pay $100 \%$ and that willing to pay $80 \%$ would agree. In other words, $36.8 \%(27.5 \%+9.3 \%)$ of the owners would invest; Similarly, if required to invest $50 \%, 55.3 \%(27.5 \%+9.3 \%+18.5 \%)$ of the owners would invest; And if required to invest 20\%, $74.4 \%(27.5 \%+9.3 \%+18.5 \%+19.1 \%)$ of the owners would invest (Figure 4). Under this condition, if homeowners only need bear $20 \%$ of the overall cost, $74.4 \%$ (which is greater than two third) of the homeowners would agree to invest and the retrofit could be carried out.

Table 1. Frequency and percentage of respondents willing to pay different cost ratios.

\begin{tabular}{ccc}
\hline Cost Ratio Willing to Pay & Frequency & Percent \\
\hline 0 & 94 & 25.6 \\
$20 \%$ & 70 & 19.1 \\
$50 \%$ & 68 & 18.5 \\
$80 \%$ & 34 & 9.3 \\
$100 \%$ & 101 & 27.5 \\
Total & 367 & 100.0 \\
\hline
\end{tabular}




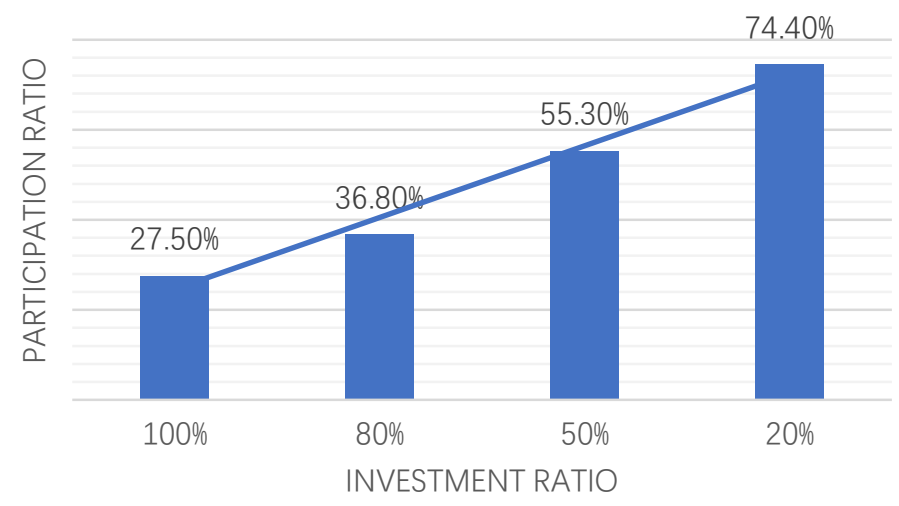

Figure 4. Relationship between participation ratio and investment ratio.

Bivariate correlation analysis of various influencing factors and the WTP was conducted by IBM SPSS Statistics Software 25, and the results are shown in Table 2. In Table 2, "PC" stands for the Pearson correlation of two factors and "Sig." stands for the significant level of correlation. For instance, the Pearson correlation between WTP and education is 0.382 , indicating significance at the 0.01 level. We fail to include "income level" in the calculation because nearly half of the respondents chose "do not want to disclose".

Table 2. Bivariate correlation analysis results of influencing factors and WTP.

\begin{tabular}{|c|c|c|c|c|c|c|c|c|c|}
\hline Factors & & WTP & Knowledge & Experience & $\begin{array}{l}\text { Floor } \\
\text { area }\end{array}$ & $\begin{array}{c}\text { Building } \\
\text { Age }\end{array}$ & Gender & Age & Education \\
\hline \multirow{2}{*}{ WTP } & PC & 1 & 0.062 & $-0.188^{* *}$ & $0.309^{* *}$ & -0.074 & 0.101 & $-0.310 * *$ & $0.382 * *$ \\
\hline & Sig. & & 0.239 & 0.000 & 0.000 & 0.157 & 0.053 & 0.000 & 0.000 \\
\hline \multirow{2}{*}{ Knowledge } & PC & 0.062 & 1 & $0.199^{* *}$ & -0.109 * & 0.069 & 0.068 & 0.068 & -0.051 \\
\hline & Sig. & 0.239 & & 0.000 & 0.037 & 0.186 & 0.195 & 0.193 & 0.327 \\
\hline \multirow{2}{*}{ Experience } & PC & $-0.188^{* *}$ & $0.199 * *$ & 1 & -0.099 & $0.211^{* *}$ & -0.076 & $0.263 * *$ & $-0.186^{* *}$ \\
\hline & Sig. & 0.000 & 0.000 & & 0.058 & 0.000 & 0.144 & 0.000 & 0.000 \\
\hline \multirow{2}{*}{$\begin{array}{c}\text { Floor } \\
\text { area }\end{array}$} & PC & $0.309 * *$ & -0.109 * & -0.099 & 1 & $-0.296^{* *}$ & -0.001 & $-0.303^{* *}$ & $0.391^{* *}$ \\
\hline & Sig. & 0.000 & 0.037 & 0.058 & & 0.000 & 0.981 & 0.000 & 0.000 \\
\hline Building & PC & -0.074 & 0.069 & $0.211^{* *}$ & $-0.296 * *$ & 1 & 0.018 & $0.207 * *$ & $-0.240^{* *}$ \\
\hline Age & Sig. & 0.157 & 0.186 & 0.000 & 0.000 & & 0.726 & 0.000 & 0.000 \\
\hline \multirow{2}{*}{ Gender } & PC & 0.101 & 0.068 & -0.076 & -0.001 & 0.018 & 1 & -0.018 & -0.003 \\
\hline & Sig. & 0.053 & 0.195 & 0.144 & 0.981 & 0.726 & & 0.725 & 0.960 \\
\hline \multirow{2}{*}{ Age } & PC & $-0.310 * *$ & 0.068 & $0.263^{* *}$ & $-0.303^{* *}$ & $0.207^{* *}$ & -0.018 & 1 & $-0.706^{* *}$ \\
\hline & Sig. & 0.000 & 0.193 & 0.000 & 0.000 & 0.000 & 0.725 & & 0.000 \\
\hline \multirow{2}{*}{ Education } & PC & $0.382^{* *}$ & -0.051 & $-0.186^{* *}$ & $0.391^{* *}$ & $-0.240^{* *}$ & -0.003 & $-0.706^{* *}$ & 1 \\
\hline & Sig. & 0.000 & 0.327 & 0.000 & 0.000 & 0.000 & 0.960 & 0.000 & \\
\hline
\end{tabular}

**. Correlation is significant at the 0.01 level (2-tailed). *. Correlation is significant at the 0.05 level (2-tailed).

According to the results of the bivariate correlation analysis, the respondents' retrofit experience is significantly positively correlated with their knowledge of the content of the retrofit, which is consistent with previous experiences and the hypothesis of this study. However, unlike the previous literature and the hypothesis of this study, no significant correlation was found between the respondents' willingness to pay for the retrofit and their related knowledge.

Meanwhile, the respondents' retrofit experience, the age of their dwelling, and their own age have a significant negative correlation with their willingness to pay. The influence of building age and homeowner's age is not surprising, but the correlation between retrofit experience and willingness to pay is contrary to our expectations. Both floor area and education level of respondents have a significant positive correlation with WTP. Besides, gender did not show a significant correlation. 


\subsection{Summary}

Firstly, regarding the willingness to invest, both qualitative and quantitative methods have reached similar results that some homeowners are willing to invest. The results of the interviews were quantified by the questionnaire through the willingness to pay.

Secondly, about the influencing factors, it has been verified by the questionnaire that 5 of 8 preset factors are related to the willingness to pay. The reasons for the influences of these five factors can all be explained by the interview results. Besides, two preset factors did not show a correlation with the willingness to pay, and no valid data were collected for one factor. The cause and the impact of these factors, together with other factors that only appear in interviews, will be comprehensively analyzed in the discussion section.

\section{Discussion}

Both qualitative and quantitative research results showed that some interviewees have the willingness to invest in energy efficiency retrofit. However, at the current stage, the homeowners cannot make a full investment towards the retrofit. Homeowners are the main beneficiary of energy efficiency retrofit instead of the only beneficiary. Therefore, the financing of the retrofit should not only conform to the current policy but also conform to the reality of the homeowner's willingness. Considering the principle of "two-thirds of the owners' agreement is needed", in order to ensure the smooth execution of the retrofit with homeowners' participation, the homeowners' investment should be no more than $20 \%$ of the total cost, based on the WTP evaluated from quantitative research. To accelerate the promotion of energy efficiency retrofit, on the one hand, policymakers need to find other financing sources. On the other hand, the analysis of homeowners' willingness and its influencing factors is needed to optimize the current policies and to increase the homeowners' willingness to invest. The focus of this study is mainly the latter approach.

In qualitative analysis, both floor area and education level showed a positive correlation with WTP. In China, the floor area of a home owned by a person reflects his wealthy status to a certain extent. It could be speculated that high-income homeowners who have large floor area homes are more willing to make an investment towards retrofit in China. To a certain degree, the correlation between floor area and WTP makes up for the questionnaire's failure to obtain the income of the respondents. The positive influence of education was consistent with previous research.

Based on the comprehensive analysis of qualitative and quantitative results, the age of the homeowner and the age of the building can be considered as the most significant negative influencing factors. Both of these factors have been mentioned in the in-depth interviews, and the analysis of the questionnaire results also indicated a significant correlation.

There are several speculations about the reasons for the negative impact of the age of the homeowners on the willingness to invest. Firstly, as mentioned by the homeowners, the uncertainty about their own lifespan makes them feel that the retrofit is not worthwhile, because they are not sure how long they can continue living in the retrofitted homes. The second reason is the differences in the view of consumption among generations, which influence has been discussed by researchers in many countries as well as in China [55]. The second reason is the change in economic system. In the past 40 years, after China's Reform and Opening-up, China's society and economy have experienced dramatic changes. There is a huge difference in terms of life experiences and view of consumption among those who were born and grown up before and after the Reform and Opening-up. The younger generation is more decisive in consumption decisions, and are more willing to engage in enjoyment consumption. This phenomenon can also be found in energy consumption. As for the third reason, it can be summarized as homeowners' view of consumption about housing retrofit has been affected by China's housing commercialization reforms, either directly or indirectly. The housing commercialization reforms had been introduced in the background. Homeowners born after the 1980s are accustomed to the privatization of residential buildings. They believe that they have the right to retrofit their own property and need to bear the cost of it. On the other hand, those who were born earlier are still 
affected by the era of welfare housing and believe that the government or construction companies should bear the responsibility of maintaining and retrofitting their homes, no matter these homes are purchased public housing or commercial housing. This is also relevant to the influencing factors "definition of responsibility". The homeowners may be affected by one or all three factors.

The main reason for the negative impact of the building age is related to the floor area and the construction quality. As introduced in the research background section, residential buildings built at an early age usually have a smaller living area that cannot be improved by retrofit. These buildings are also outdated in terms of structure and construction technology, which brings potential safety hazards and increases the cost of reinforcement and retrofit. Thus, homeowners of "Old, Aged and Small" buildings are unwilling to invest in the retrofit.

The impact of retrofit experience and the knowledge of retrofit on the investment willingness needs to be discussed together. According to the questionnaire results, retrofit experience is positively correlated with the homeowners' degree of knowledge but is negatively correlated with their willingness to pay. Meanwhile, the degree of knowledge is not significantly correlated with the willingness to pay. The findings contradict previous studies and the expected effect of demonstration projects. The experience of participating in the demonstration retrofit project is expected to increase the degree of knowledge, and sufficient knowledge should increase the homeowners' willingness to invest. According to the interview results, the main reason for this contradiction is that the homeowners are not satisfied with their past retrofit experiences, including the outcomes of the retrofit and the changes in retrofit policies. The past retrofit projects have many defects in terms of design, material selection, construction, management, etc., which have caused the dissatisfaction of the homeowners and reduced their willingness to undertake retrofit in the future. Moreover, given the fact that retrofit projects were mainly funded by central and local governments, homeowners would feel unfair if they are required to invest in future projects, no matter they have retrofit experience or not. While the past retrofit projects played a role in propaganda and improved the understanding of homeowners, it must be acknowledged that these government-funded projects harm social equity and thus hinder homeowners' investment.

The results can be interpreted from different aspects. In terms of policy aspect, targeted policies can be formulated based on the causes of the influencing factors mentioned above. In terms of the technical aspect, considering that some homeowners are dissatisfied with the previous retrofit results, construction and design techniques need to be innovated according to their requirements. The homeowners' attitude and comments collected from the in-depth interviews can be used as a reference. In terms of research methods, this article proved that a combination of qualitative and quantitative methods can be used for homeowner investment research in China and found that China's unique policies and climate background have a corresponding impact on the intentions of homeowners. In future research, the existing methods can be generalized to cities located in other climate regions in China.

For the policymakers, among all the factors that affect homeowners' investment, some factors are difficult to overcome, such as the floor area of the home which involve property rights issues. Meanwhile, it is possible to enhance some drivers and mitigate some barriers.

As a driver that has been widely recognized by the homeowners, economic incentives can play a greater role. First of all, through the implementation of housing energy labeling policies, energy efficiency retrofit can increase the market value of residential buildings, and thereby monetizing the results of the retrofit. Meanwhile, the clarification of the value of energy efficiency retrofit can also relieve the elderly's anxiety about the return on investment. In Europe, energy labeling has been put into practice for many years. For example, Brounen proved that the Dutch building energy labels have increased the market value of energy-efficient buildings [56]. In China, energy labels have been used on a variety of household appliances and have some legislation and management experience. Even 
if metered heating cannot be realized quickly due to barriers such as free ridership in collective housing, there are other approaches for homeowners to obtain the economic benefits of energy efficiency retrofit, such as reducing heating charges and increasing heating subsidies for retrofitted buildings. Increasing heating charges on energy-inefficient residential buildings can also encourage homeowners to consider energy conservation to a certain extent.

The government must change the financial model for energy efficiency retrofit projects and stop the one-size-fits-all financial subsidies that harm the feeling of fairness. First of all, the transformation from retrofit subsidies to incentives should be promoted. Homeowners should be able to apply for incentives if their homes pass the post-retrofit assessment. Next, issuing low-interest or interest-free special loans for energy efficiency retrofit to the homeowners. The effectiveness of providing loans to homeowners who need energy efficiency retrofit has been proved in both Germany and Switzerland.

Besides, due to the peculiarities of the Chinese family structure, the opinions of adult children have a great influence on the investment decisions of the elderly. The propaganda of the retrofit should not only focus on the advantages of energy efficiency but can also encourage adult children to support their parents to undertake retrofits. What needs to be clear is, even if the finances of parents and children are considered together, energy-saving retrofit can still be considered as profitable.

\section{Conclusions}

It can be found that homeowners in Tianjin have a certain extent of WTP, but it cannot fully cover the cost of energy efficiency retrofit. Factors that influence homeowners' investment are summarized through in-depth interviews, and some of them are added to the questionnaire for quantitative research. Among the 8 presupposed factors, the age and education level of the homeowner, the age and floor area of the building, and the retrofit experience showed a statistical correlation with WTP. The causes of various influencing factors were analyzed, and possible policy measures to encourage homeowners to invest in energy efficiency retrofit were discussed accordingly.

From the perspective of policymaking, based on ensuring the quality of construction, the main issue to promote the homeowner's investment in energy efficiency retrofit is to solve economic problems. Establishing a way to let the homeowners obtain energy-saving benefits can encourage them to invest. Providing loans to homeowners who lack funds is expected to trigger the investment of more homeowners. Although the energy efficiency retrofit project invested by the government can improve homeowners' relevant knowledge, if it is restricted to the level of pilot projects, it will affect the fairness and influence the homeowners' enthusiasm for investment.

This study is subject to several limitations that might limit the applicability of the findings. Firstly, the WTP stated by the interviewees might not reflect their actual WTP precisely. They might overstate or understate the price of retrofit because of their different understanding of the purpose of the survey. It does not affect the analysis and policy recommendations in this study. However, in order to give a precise estimation of homeowners' willingness to pay, other evaluation methods or approaches are needed in further studies. Secondly, this paper does not discuss the WTP for any specific part of the building, such as roofs or windows. Homeowners may perceive some parts such as windows as their own belongings. Meanwhile, they feel that they are less responsible for other parts, including roofs and external walls, because "someone else should take care of them", despite the fact that they also own the property rights to these parts. It will bring a deviation in their willingness to pay for the retrofit of different parts, which is worthy of further exploration. Thirdly, the sample of the questionnaire survey is not a representative sample of China's population. The results would be more comprehensive if information on homeowners from other provinces/cities can be collected.

Considering the transformation of housing policies and the role of the central and local governments, more attention needs to be paid to the perspective of homeowners in 
future research on residential retrofit. Key points include how to analyze homeowner's attitude and willingness and how to guide their decision effectively.

Author Contributions: Investigation, data curation, and writing—original draft preparation, C.H.; writing - review and editing, J.M.; supervision and funding acquisition, K.S. All authors have read and agreed to the published version of the manuscript.

Funding: This research was funded by Ministry of Education of the People's Republic of China, grant number 15JZD025.

Conflicts of Interest: The authors declare no conflict of interest.

\section{Appendix A}

Table A1. Respondent information of in-depth interview.

\begin{tabular}{|c|c|c|c|c|c|}
\hline $\begin{array}{l}\text { Respondent } \\
\text { Number }\end{array}$ & Date & $\begin{array}{c}\text { Residential } \\
\text { District Name }\end{array}$ & Built Year & $\begin{array}{l}\text { Respondent } \\
\text { Age }\end{array}$ & $\begin{array}{c}\text { Respondent } \\
\text { Gender }\end{array}$ \\
\hline 1 & July.2019 & Lefu Li & 1984 & 75 & Female \\
\hline 2 & July.2019 & Lechang Li & 1985 & 35 & Male \\
\hline 3 & July.2019 & Zhenhe Li & 1985 & 35 & Female \\
\hline 4 & July.2019 & Zhenhe Li & 1985 & 60 & Female \\
\hline 5 & July.2019 & Nandabei Cun & 1992 & 52 & Male \\
\hline 6 & July.2019 & Yibindong Li & 1983 & 60 & Female \\
\hline 7 & July.2019 & Yibindong Li & 1983 & 62 & Male \\
\hline 8 & July.2019 & Yibindong Li & 1983 & 66 & Male \\
\hline 9 & July.2019 & Yibindong Li & 1983 & 71 & Male \\
\hline 10 & July.2019 & Yibindong Li & 1983 & 63 & Male \\
\hline 11 & July.2019 & Yibindong Li & 1983 & 55 & Female \\
\hline 12 & July.2019 & Yibindong Li & 1983 & 69 & Female \\
\hline 13 & July.2019 & Yibinbei Li & 1983 & 60 & Female \\
\hline 14 & July.2019 & Nanfeng Li & 1985 & 65 & Female \\
\hline 15 & July.2019 & Nanfeng Li & 1985 & 35 & Female \\
\hline 16 & July.2019 & Tiandaliu Cun & 1995 & 40 & Female \\
\hline 17 & July.2019 & Huazhang Li & 1991 & 48 & Male \\
\hline 18 & June.2019 & Huagang Li & 1983 & 70 & Female \\
\hline 19 & June.2019 & Huagang Li & 1983 & 55 & Female \\
\hline 20 & June.2019 & Hongkan Flat & 2001 & 54 & Male \\
\hline 21 & June.2019 & Bihua Li & 1998 & 30 & Female \\
\hline 22 & June.2019 & Yunhua Li & 2002 & 32 & Female \\
\hline 23 & June.2019 & Zhuhua Li & 2002 & 31 & Male \\
\hline 24 & June.2019 & Zhuhua Li & 2002 & 31 & Female \\
\hline
\end{tabular}

\section{Appendix B}

Table A2. Questions in questionnaire.

\begin{tabular}{cc}
\hline Question & Options or Blank \\
\hline How do you know about the EERRB? & A. Quite well B. Good, to some extent C. Not at all \\
\hline Have you ever experienced any EERRB? & A. Yes B. No \\
\hline What percentage are you willing to pay for EERRB? & \\
\hline The floor area of you home? & A. Female B. Male \\
\hline The year you home was built? & A. Junior high school or below B. Senior middle school C. College \\
Your age? & degree D. Bachelor degree E. Master degree or higher \\
\hline Your gender? &
\end{tabular}




\section{References}

1. The State Council of The People's Republic of China. Comprehensive Work Plan for Energy Conservation and Emission Reduction During the 13th Five-Year Plan; Compilation and Translation Bureau Central, Central Committee of the Communist Party of China, Translators, Compilation \& Translation Press: Beijing, China, 2016.

2. The State Council of The People's Republic of China. Li, Keqiang Report on The Work of The Government. In Proceedings of the Third Session of the 13th National People's Congress of the People's Republic of China, Beijing, China, 22 May 2020.

3. Liqiang, H. Nation Pushes Renovation of Aging Residential Areas. Available online: http://english.www.gov.cn/news/policy_ briefings/2019/07/02/content_281476744010478.htm (accessed on 2 July 2019).

4. Gupta, R.; Gregg, M. Do deep low carbon domestic retrofits actually work? Energy and Buildings 2016, 129, 330-343. [CrossRef]

5. Yan, D.; Zhe, T.; Yong, W.; \& Neng, Z. Achievements and suggestions of heat metering and energy efficiency retrofit for existing residential buildings in northern heating regions of china. Energy Policy 2011, 39, 4675-4682. [CrossRef]

6. Liu, W.; Zhang, J.; Bluemling, B.; Mol, A.P.J.; Wang, C. Public participation in energy saving retrofitting of residential buildings in China. Appl. Energy 2015, 147, 287-296. [CrossRef]

7. Jian, S. Study on sustainable renovation of urban existing housing at abroad and China. Ph.D. Thesis, Dalian University of Technology, Dalian, China, June 2013. (In Chinese).

8. Xu, P.; Xu, T.; Shen, P. Energy and behavioral impacts of integrative retrofits for residential buildings: What is at stake for building energy policy reforms in northern China? Energy Policy 2013, 52, 667-676. [CrossRef]

9. China to renovate old urban communities. Available online: http://english.www.gov.cn/policies/latestreleases/202007/20/ content_WS5f156515c6d00bd0989c642d.html (accessed on 20 July 2020).

10. Trotta, G. The determinants of energy efficient retrofit investments in the English residential sector. Energy Policy 2018, 120, 175-182. [CrossRef]

11. Chih-Pei, H.U.; Chang, Y.Y.; John, W. Creswell, research design: Qualitative, quantitative, and mixed methods approaches. J. Soc. Adm. Sci. 2017, 4, 205-207.

12. David, W.; Linda, G. Architectural Research Methods. In Architecture Research Methods, 2nd ed; Wiley: Hoboken, NJ, USA, 2013.

13. Friedman, C.; Becker, N.; Erell, E. Retrofitting residential building envelopes for energy 2nd ed efficiency: Motivations of individual homeowners in Israel. J. Environ. Plan. Manag. 2017, 61, 1805-1827. [CrossRef]

14. Klöckner, C.A.; Nayum, A. Specific barriers and drivers in different stages of decision-making about energy efficiency upgrades in private homes. Front. Psychol. 2016, 7, 1-14. [CrossRef] [PubMed]

15. Alberini, A.; Banfi, S.; Ramseier, C. Energy efficiency investments in the home: Swiss homeowners and expectations about future energy prices. Energy J. 2013, 34. [CrossRef]

16. Banfi, S.; Farsi, M.; Filippini, M.; Jakob, M. Willingness to pay for energy-saving measures in residential buildings. Energy Econ. 2008, 30, 503-516. [CrossRef]

17. Achtnicht, M. Do environmental benefits matter? A choice experiment among house owners in germany. SSRN Electron. J. 2010. [CrossRef]

18. Bjørneboe, M.G.; Svendsen, S.; Heller, A. Initiatives for the energy renovation of single-family houses in Denmark evaluated on the basis of barriers and motivators. Energy Build. 2018, 167, 347-358. [CrossRef]

19. Gillingham, K.; Newell, R.G.; Palmer, K. Energy efficiency economics and policy. Annu. Rev. Resour. Econ. 2009, 1, 597-620. [CrossRef]

20. Wilson, C.; Pettifor, H.; Chryssochoidis, G. Quantitative modelling of why and how homeowners decide to renovate energy efficiently. Appl. Energy 2018, 212, 1333-1344. [CrossRef]

21. Jakob, M. Marginal costs and co-benefits of energy efficiency investments. Energy Policy 2006, 34, 172-187. [CrossRef]

22. Mankiw, N.G. Principles of Economics, 7th ed.; Cengage Learning: Boston, MA, USA, 2015; p. 136.

23. Breidert, C.; Hahsler, M.; Reutterer, T. A review of methods for measuring willingness-to-pay. Innov. Mark. 2006, 2, 8-32.

24. Kwak, S.-Y.; Yoo, S.-H.; Kwak, S.-J. Valuing energy-saving measures in residential buildings: A choice experiment study. Energy Policy 2010, 38, 673-677. [CrossRef]

25. Vance, C.; Peter, G. Willingness to pay for energy conservation and free-ridership on subsidization: Evidence from Germany. Energy J. 2009, 30, 135-153.

26. Collins, M.; Curtis, J. Willingness-to-pay and free-riding in a national energy efficiency retrofit grant scheme. Energy Policy 2018, 118, 211-220. [CrossRef]

27. Nair, G.; Gustavsson, L.; Mahapatra, K. Factors influencing energy efficiency investments in existing Swedish residential buildings. Energy Policy 2010, 38, 2956-2963. [CrossRef]

28. Poortinga, W.; Steg, L.; Vlek, C.; Wiersma, G. Household preferences for energy-saving measures: A conjoint analysis. J. Econ. Psychol. 2003, 24, 49-64. [CrossRef]

29. Gamtessa, S.F. An explanation of residential energy-efficiency retrofit behavior in Canada. Energy Build. 2013, 57, 155-164. [CrossRef]

30. Bartiaux, F.; Vekemans, G.; Gram-Hanssen, K.; Maes, D.; Cantaert, M.; Spies, B.; Desmedt, J. Socio-Technical Factors Influencing Residential Energy Consumption (SEREC); Belgian Science Policy: Brussel, Belgium, 2006.

31. Black, J.S.; Stern, P.C.; Elworth, J.T. Personal and contextual influences on househould energy adaptations. J. Appl. Psychol. 1985, 70, 3-21. [CrossRef] 
32. Costanzo, M.; Archer, D.; Aronson, E.; Pettigrew, T. Energy conservation behavior: The difficult path from information to action. Am. Psychol. 1986, 41, 521-528. [CrossRef]

33. Dillman, D.A.; Rosa, E.A.; Dillman, J.J. Lifestyle and home energy conservation in the United States: The poor accept lifestyle cutbacks while the wealthy invest in conservation. J. Econ. Psychol. 1983, 3, 299-315. [CrossRef]

34. Caird, S.; Herring, H.; Roy, R. Can consumers save energy? Results from surveys of consumer adoption and use of low and zero carbon technologies. In Proceedings of the ECEEE 2007 Summer Study, Côte d'Azur, France, 4-9 June 2007.

35. Barr, S.; Gilg, A.W.; Ford, N. The household energy gap: Examining the divide between habitual- and purchase-related conservation behaviours. Energy Policy 2005, 33, 1425-1444. [CrossRef]

36. Ürge-Vorsatz, D.; Hauff, J. Drivers of market transformation: Analysis of the Hungarian lighting success story. Energy Policy 2001, 29, 801-810. [CrossRef]

37. Phillips, Y. Landlords versus tenants: Information asymmetry and mismatched preferences for home energy efficiency. Energy Policy 2012, 45, 112-121. [CrossRef]

38. Murphy, L. The influence of energy audits on the energy efficiency investments of private owner-occupied households in the Netherlands. Energy Policy 2014, 65, 398-407. [CrossRef]

39. Judson, E.P.; Maller, C. Housing renovations and energy efficiency: Insights from homeowners' practices. Build. Res. Inf. 2014, 42, 501-511. [CrossRef]

40. Nauleau, M.-L. Free-riding on tax credits for home insulation in France: An econometric assessment using panel data. Energy Econ. 2014, 46, 78-92. [CrossRef]

41. Cameron, T.A. A nested logit model of energy conservation activity by owners of existing single family dwellings. Rev. Econ. Stat. 1985, 67, 205-211. [CrossRef]

42. Spetic, W.; Kozak, A.R.; Cohen, D. Willingness to pay and preferences for healthy home attributes in Canada. For. Prod. J. 2005, $55,19-24$.

43. Pettifor, H.; Wilson, C.; Chryssochoidis, G. The appeal of the green deal: Empirical evidence for the influence of energy efficiency policy on renovating homeowners. Energy Policy 2015, 79, 161-176. [CrossRef]

44. Mahapatra, K.; Gustavsson, L. An adopter-centric approach to analyze the diffusion patterns of innovative residential heating systems in Sweden. Energy Policy 2008, 36, 577-590. [CrossRef]

45. Lindén, A.-L.; Carlsson-Kanyama, A.; Eriksson, B. Efficient and inefficient aspects of residential energy behaviour: What are the policy instruments for change? Energy Policy 2006, 34, 1918-1927. [CrossRef]

46. Yuming, L. Study on Economic Incentive for Improving Energy Efficiency of Existing Residential Buildings. Ph.D. Thesis, Bejing Jiaotong University, Beijing, China, 2009. (In Chinese).

47. Yi, J. China's building energy consumption trends and energy saving priorities. Jian She Ke Ji 2006, 7, 10-13. (In Chinese)

48. China Association of building energy efficiency. China Building Energy Research Report; Building Energy Research Center Thisnhua University: Beijing, China, 2019. (In Chinese)

49. Building Energy Research Center of Tsinghua University. Annual Report on China building Energy Efficiency; China Architecture \& Building Press: Beijing, China, 2017. (In Chinese)

50. Dongyan, L. Fiscal and tax policy support for energy efficiency retrofit for existing residential buildings in China's northern heating region. Energy Policy 2009, 37, 2113-2118. [CrossRef]

51. Yang, H.; Liu, L.; Li, X.; Liu, C.; Jones, P. Tailored domestic retrofit decision making towards integrated performance targets in Tianjin, China. Energy Build. 2017, 140, 480-500. [CrossRef]

52. Guo, N.; Nie, L. Out of the "Classic Pattern" —Thoughts on the contemporary housing design. Xin Jian Zhu 2001, 2, 4-7. (In Chinese)

53. Liu, D.; Jiang, H.; Yu, L. The development of China's housing industrialization and its technology evolution. Jian Zhu Xue Bao 2012, 4, 10-18. (In Chinese)

54. Chen, X. Qualitative Research in Social Sciences, 1st ed.; Educational Science Publishing House: Beijing, China, 2000. (In Chinese)

55. Bardazzi, R.; Pazienza, M.G. When I was your age: Generational effects on long-run residential energy consumption in Italy. Energy Res. Soc. Sci. 2020, 70, 101611. [CrossRef]

56. Brounen, D.; Kok, N. On the economics of energy labels in the housing market. J. Environ. Econ. Manag. 2011, 62, 166-179. [CrossRef] 